\section{ANALISIS TINGKAT PENERIMAAN MAHASISWA PENDIDIKAN TEKNOLOGI PERTANIAN TERHADAP KELASE MENGGUNAKAN TECHNOLOGY ACCEPTANCE MODEL}

\author{
Andi Sukainah ${ }^{1}$ dan Reski Praja Putra ${ }^{2}$ \\ Universitas Negeri Makassar ${ }^{1,2}$ \\ Email:andisukainah@yahoo.com¹
}

http://ojs.unm.ac.id/index.php/Insani/index

\begin{abstract}
Abstrak. Tujuan penelitian ini adalah untuk mengetahui analisis penerapan dan tingkat penerimaan mahasiswa PTP terhadap Kelase, serta korelasi dan linieritas variabel dalam metode Technology Accepted Model (TAM). Hasil menunjukkan tingkat persepsi penerimaan mahasiswa PTP sangat tinggi, yaitu antara $72.25-94.24 \%$. Tingkat penerimaan mahasiswa PTP dipengaruhi oleh variabel persepsi kemudahan penggunaan dan persepsi kebermanfaatan. Variabel Technology Acceptance Model (TAM) memiliki korelasi yang signifikan. Pengaruh variabel persepsi kemudahan penggunaan dan persepsi kebermanfaatan terhadap penerimaan, yaitu $60 \%$. Model persamaan regresi yang dihasilkan memperlihatkan variabel persepsi kemudahan penggunaan (x1) dan persepsi kebermanfaatan ( $x 2$ ) bernilai positif. Hubungan linieritas dari ketiga variabel tersebut menunjukkan bahwa semakin baik persepsi kemudahan penggunaan dan semakin tinggi persepsi kebermanfaatan aplikasi Kelase, maka penerimaan mahasiswa di Program Studi PTP akan semakin meningkat.
\end{abstract}

Kata Kunci: E-learning, Pendidikan Teknologi Pertanian, Kelase, Technology Accepted Model

\section{INDONESIAN JOURNAL OF EDUCATIONAL STUDIES (IJES)}

\section{E-ISSN: 2621-6744 \\ P-ISSN: 2621-6736}

Submitted: January, $7^{\text {th }} 2019$

Accepted : March, $16^{\text {th }} 2019$

Abstract. The purpose of this study is to determine analysis of the application and level acceptance from EAT's student towards Kelase, as well as the correlation and linearity of variables in the Technology Accepted Model (TAM) method. The results show that the level of perception of EAT's student admissions is very high, which is between 72.25-94.24\%. The level of EAT's student acceptance is influenced by variables of perceived ease of use and usefulness perceptions. Variable Technology Acceptance Model (TAM) has significant correlation. The effect of the variables perceived ease of use and usefulness perceptions on acceptance, namely $60 \%$. The resulting regression equation model shows the perception variables of ease of use ( $x 1$ ) and the perception of usefulness $\left(x_{2}\right)$ is positive. The linearity relationship of the three variables shows that ${ }^{\text {the }}$ better perception ease of use and the higher of usefulness perception in the Kelase application, acceptance of the student at the Program Study EAT will increase. 


\section{PENDAHULUAN}

Penerapan kurikulum yang berdasarkan pada Kerangka Kualifikasi Nasional Indonesia (KKNI) sesuai Peraturan Menteri Republik Indonesia Nomor 8 Tahun 2012 menuntut lulusan Sarjana memiliki kualifikasi yang mampu untuk mengaplikasikan dan menguasai teori sesuai dengan bidang ilmu yang dipelajari, mampu mengambil keputusan yang tepat sesuai analisis informasi dan data serta memberi petunjuk alternatif pada suatu permasalahan, serta harus memiliki rasa tanggung jawab. Pendidikan Teknologi Pertanian (PTP) merupakan salah satu Program Studi di Fakultas Teknik Universitas Negeri Makassar yang telah menerapkan kurikulum sesuai dengan KKNI.

Metode pembelajaran yang digunakan di PTP masih bersifat konvensional, yaitu metode pembelajaran cenderung hanya difokuskan pada perkuliahan di ruang kuliah saja (face to face) dengan peralatan dan sarana standar. Proses ini menyebabkan komunikasi antar dosen dan mahasiswa mengenai materi ajar hanya terjadi pada saat proses perkualiahan berlangsung. Para dosen PTP telah berupaya untuk meningkatkan komunikasi antar dosen dan mahasiswa dengan memberi kesempatan pada mahasiswa untuk berkonsultasi mengenai materi ajar yang masih kurang dipahami di luar jam perkuliahan, namun sangat jarang sekali mahasiswa yang datang untuk berkonsultasi. Hal ini kemungkinan disebabkan mahasiswa memiliki rasa segan, khawatir, malu, dan takut untuk bertanya langsung pada dosen.

Metode pembelajaran yang dianggap mampu mengatasi permasalahan ini adalah metode pembelajaran E-learning. Metode E-learning merupakan metode pembelajaran yang memanfaatkan teknologi informasi dan komunikasi melalui fasilitas internet dan website, sehingga proses pembelajaran dapat tetap terjadi pada tempat dan waktu di luar jam perkuliahan formal. Metode E-learning telah mulai diterapkan di PTP. Sukainah dan Reski (2017) telah membuat pengembangan metode pembelajaran E-learning mata kuliah Mikrobiologi dengan Kelase, hasil menunjukkan program E-learning Kelase valid dan layak untuk diaplikasikan karena memiliki fitur yang telah memenuhi kriteria standard mutu E-learning, yaitu intensitas pertemuan dosen, mahasiswa, dan mahasiswa lainnya, diskusi online, penyerahan tugas secara online, ujian online, dan pengelolaan nilai secara online.

Pengembangan metode pembelajaran E-learning di PTP tidak dimaksudkan sebagai upaya untuk menggantikan metode perkuliahan konvensional secara keseluruhan, melainkan hanya sebagai upaya untuk mengkombinasikan metode pembelajaran konvensional dan E-learning agar terjadi prose pembelajaran yang lebih bervariatif sehingga mampu meningkatkan motivasi mahasiswa dalam proses pembelajaran dan komunikasi antar dosen maupun sesama mahasiswa mengenai materi ajar dapat terjalin di luar jam perkuliahan formal. Oleh karena itu, penelitian untuk mengetahui analisis penerapan dan tingkat penerimaan mahasiswa PTP terhadap Kelase perlu dikaji.

Technology Acceptance Model (TAM) merupakan salah satu teknik analisis yang dapat digunakan untuk pengujian tingkat penerimaan tersebut. Setiawan et al. (2014) TAM dapat menjadi pendekatan untuk memahami sikap pengguna terhadap 
teknologi dengan mendefinisikan beberapa faktor yang mempengaruhi penerimaan pengguna terhadap teknologi yaitu persepsi kemudahan (perceived ease of use), persepsi kemanfaatan (perceived usefulness), sikap (attitude toward using), minat (behavioral intention to use), dan kondisi nyata penggunaan sistem (actual system usage). Pengkajian ini diharapkan mampu menjelaskan kelayakan atau ketidaklayakan pemanfaatan Kelase pada beberapa program mata kuliah yang diajarkan di PTP. Tujuan penelitian ini adalah untuk mengetahui analisis penerimaan dan tingkat penerimaan mahasiswa PTP terhadap Kelase menggunakan TAM serta mengetahui korelasi dan linieritas antara variabel dalam TAM

\section{METODE PENELITIAN}

Penelitian ini menggunakan metode campuran kualitatif dan kuantitatif. Analisa kualitatif ini bertujuan untuk menguraikan data responden berdasarkan pada jawaban yang diberikan oleh responden dalam daftar pertanyaan instrumen. Analisa kuantitatif berdasarkan perhitungan-perhitungan dengan bantuan perhitungan statistik atau menggunakan angka-angka yang ada serta didukung oleh program SPSS for windows. Dalam penelitian ini yang di analisis adalah sikap mahasiswa terhadap pemanfaatan E-learning dalam peningkatan pembelajaran. Penelitian ini menggunakan pendekatan Technology Acceptance Model (TAM) yaitu pendekatan yang digunakan untuk mengukur sejauh mana tingkat penerimaan mahasiswa terhadap teknologi E-learning Kelase. Dalam perkembangannya, model TAM mengalami berbagai modifikasi. Gahtani (2001) dalam Napitupulu (2017) mengembangkan model TAM dengan menggabungkan variabel minat perilaku penggunaan dengan penggunaan sistem aktual menjadi variabel penerimaan. Oleh karena itu, penelitian ini akan menggunakan model TAM yang telah dikembangkan oleh Napitupulu (2017) yang terdiri dari tiga variabel yaitu persepsi kemudahan penggunaan (perceived ease of use), persepsi kebermanfaatan (perceived usefulness), dan penerimaan (acceptance).

Penelitian dilaksanakan di Program Studi Pendidikan Teknologi Pertanian (PTP), Fakultas Teknik (FT), Universitas Negeri Makassar (UNM). Populasi adalah wilayah generalisasi yang terdiri atas objek atau subjek yang mempunyai kualitas dan karakteristik tertentu yang telah ditetapkan untuk dipelajari dan kemudian ditarik kesimpulannya (Sugiyono, 2013). Populasi penelitian ini adalah seluruh mahasiswa Program Studi Pendidikan Teknologi Pertanian, Fakultas Teknik, Universitas Negeri Makassar. Sampel adalah bagian dari jumlah dan karakteristik yang dimiliki oleh populasi tersebut (Sugiyono, 2013). Sampel dalam penelitian ini diambil secara accidental sampling, yaitu mahasiswa Program Studi Pendidikan Teknologi Pertanian, Fakultas Teknik, Universitas Negeri Makassar, yang sedang mengambil mata kuliah berbasis E-learning Kelase pada semester Genap 2017/2018.

Operasional variabel adalah suatu pernyataan dalam bentuk yang khusus dan merupakan kriteria yang bisa diuji secara empiris (Pasolong, 2013). Variabel penelitian terdiri dari variabel bebas dan variabel terikat. Variabel terikat adalah variabel yang ingin dijelaskan berdasarkan variabel lainnya, sedangkan variabel bebas adalah variabel yang menyebabkan perubahan pada variabel terikat (Djufri dan Ilyas, 2007). Variabel bebas penelitian ini adalah persepsi kemudahan 
penggunaan (perceived ease of use) dan persepsi kebermanfaatan (perceived usefulness), sedangkan variabel terikat adalah penerimaan (acceptance)

Data dalam penelitian ini dikumpulkan melalui kuesioner. Kuesioner adalah suatu pengumpulan data melalui daftar pertanyaan yang diisi oleh responden itu sendiri (Pasolong, 2013). Teknik pengumpulan data yang dilakukan dengan memberi seperangkat pertanyaan atau pernyataan tertulis kepada responden untuk memperoleh informasi tentang analisis penerapan dan tingkat penerimaan metode pembelajaran E-learning Kelase. Skala pengukuran data dalam kuesioner menggunakan skala Likert. Skala Likert merupakan suatu pengukuran yang digunakan untuk mengukur sikap, pendapat, dan persepsi seseorang atau sekelompok orang tentang fenomena sosial (Pasolong, 2013). Dengan skala Likert item, variabel yang akan diukur dijabarkan menjadi sub variabel. Untuk keperluan analisis secara kuantitatif, maka jawaban diberi skor, yaitu sangat setuju (5), setuju (4), ragu-ragu (3), tidak setuju (2), dan sangat tidak setuju (1).

Instrumen berupa kuesioner tertutup dan responden hanya menjawab atau memilih jawaban yang sesuai. Pernyataan-pernyataan yang ada pada kuesioner tersebut berdasarkan pada hasil studi terhadap literatur seperti buku, jurnal karya ilmiah dan penelitian, serta kuesioner yang telah digunakan pada penelitianpenelitian sebelumnya. Kuesioner terdiri atas dua bagian. Bagian pertama merupakan pernyataan tentang identitas responden yang terdiri dari nama lengkap, jenis kelamin, usia, tahun pelajaran, perkerjaan yang dibatasi sebagai mahasiswa di PTP FT UNM. Bagian kedua terdiri dari pernyataan tertutup dari variabel persepsi kemudahan penggunaan (perceived ease of use), persepsi kebermanfaatan (perceived usefulness), dan penerimaan (acceptance).

Uji validitas digunakan untuk mengukur sejauh mana alat ukur yang digunakan dalam penelitian sesuai dengan tujuan penelitian (Sekaran, 2000). Suatu alat ukur bisa dikatakan valid jika mampu menunjukkan sejauh mana ketepatan dan kecermatan suatu alat ukur dalam melakukan fungsi ukurnya (Sugiyono, 2009). Uji validitas pada fokusnya berfungsi untuk mengetahui seberapa baik dimensi dan elemen konsep dapat diterapkan terhadap data yang akan diolah (Sekaran, 2000). Uji validitas butir digunakan untuk menguji apakah tiap butir pertanyaan benarbenar telah mengungkapkan faktor atau individu yang ingin diselidiki (internal consistency). Asumsi bahwa tiap butir dalam satu faktor mengungkapkan faktor yang bersangkutan, maka skor butir harus mempunyai korelasi positif dengan total skor faktor (Sekaran, 2000). Model korelasi yang digunakan adalah model korelasi moment tangkar (product moment pearson correlation) dan diperhitungkan menggunakan software SPSS.

Uji reliabilitas digunakan untuk mengungkapkan stabilitas internal dari jawaban responden dalam satu variabel. Hal ini dilakukan untuk mengetahui sejauh mana pengukuran dapat memberikan hasil yang tidak berbeda (konsisten), jika dilakukan kembali pada subyek yang sama (Sekaran, 2000). Uji reliabilitas dalam penelitian ini menggunakan skor Cronbach Alpha dengan derajat kepercayaan 95\%. Reliabilitas dinyatakan dengan koefisien alpha yang mempunyai rentang antara 0 sampai 1. Semakin mendekati angka 1 berarti semakin tinggi reliabilitasnya. Pengolahan data dan pembuatan gambar dilakukan menggunakan perangkat lunak 
microsoft excel 2013. Analisis deskriptif, analisis validitas, reliabilitas, dan analisis linier berganda diolah menggunakan perangkat lunak IBM SPSS 20.0.

\section{HASIL DAN PEMBAHASAN}

\section{Deskripsi Persepsi Kemudahan Penggunaan (Perceived Easy of Use)}

Variabel persepsi kemudahan penggunaan (perceived easy of use) terdiri dari 8 sub indikator, yaitu mudah dipelajari, mudah digunakan, mudah dikontrol, jelas dan mudah dimengerti, mudah dipahami, fleksibel, mudah untuk menjadi terampil, dan mudah ditemukan. Hasil penilaian responden terhadap persepsi kemudahan penggunaan (perceived easy of use) disajikan pada Tabel 3. Seluruh sub indikator yang digunakan dalam variabel persepsi kemudahan penggunaan (perceived easy of use) bersifat valid dan reliabel. Hasil ini ditunjukkan oleh nilai korelasi Pearson masing-masing sub indikator yang berada pada kisaran antara 0.573-0.788, kisaran ini menunjukkan korelasi yang signifikan pada taraf 0.01 (valid). Selain itu, nilai Kaiser-Meyer-Olkin Measure of Sampling Adequace (KMO MSA) dari variabel persepsi kemudahan penggunaan (perceived easy of use) adalah 0.796 dengan nilai factor loading masing-masing sub indikator berkisar antara 0.538-0.805. Nilai ini semakin menjelaskan bahwa variabel ini bersifat valid. Menurut Hair et al. (2010) dalam Latan dan Temalagi (2013) instrument kuesioner dinyatakan valid jika memiliki nilai KMO MSA $\geq 0.5$ dan factor loading $\geq 0.7$, akan tetapi nilai factor loading 0.5-0.6 masih dapat diterima.

Indikator yang digunakan dalam pengukuran variabel persepsi kemudahan penggunaan (perceived easy of use) juga bersifat reliabel. Hal ini dapat dilihat pada nilai Cronbach's Alpha yang dihasilkan oleh masing-masing sub indikator dalam variabel ini lebih besar dari 0.70 (>0.70). Nilai Cronbach's Alpha masing-masing sub indikator berkisar antara 0.829-0.859 (Lampiran 7.1). Suatu kostruk atau variabel dinyatakan reliabel jika menghasilkan angka Cronbach's Alpha $>0.70$, walaupun nilai 0.60-0.70 masih dapat diterima (Hair et al. 2010 dalam Latan dan Temalagi, 2013).

Nilai rata-rata dari masing-masing sub indikator berada pada kisaran 3.79-4.06, kisaran ini menunjukkan bahwa mahasiswa PTP menyetujui pernyataan yang diberikan pada masing-masing sub indikator. Umumnya, jumlah mahasiswa PTP yang memberikan respon setuju pada sub indikator variabel persepsi kemudahan penggunaan (perceived easy of use) berada pada kisaran 104-134 orang (54.45$62.83 \%$ ), bahkan beberapa mahasiswa PTP menyatakan sangat setuju dengan peryataan pada masing-masing sub indikator variabel ini. Jumlah mahasiswa PTP yang menyatakan sangat setuju berada pada kisaran 23 (12.04\%) hingga 43 orang (22.51\%). Hasil ini menunjukkan bahwa mahasiswa setuju bahwa program Kelase adalah salah satu program E-learning yang mudah dipelajari, mudah digunakan, dapat dikontrol, jelas dan mudah dimengerti, mudah dipahami, fleksibel, mudah untuk menjadi terampil, dan mudah ditemukan.

Mahasiswa PTP setuju bahwa program Kelase bersifat jelas dan mudah dimengerti. Pada saat pembuatan akun baru pada program Kelase, tampilan yang ada bersifat sangat jelas dan memudahkan pengguna dalam pembuatan akun baru. Pada menu utama Kelase hanya terdiri dua pilihan, yaitu "Daftar Sekarang" dan “Masuk". Menu "Daftar Sekarang” ditujukan bagi mahasiswa yang belum memiliki 
akun di Kelase, pada menu ini tersedia form registrasi yang harus diisi oleh mahasiswa, sedangkan menu "Masuk" diperuntukkan bagi mahasiswa yang telah memiliki akun di Kelase.

Akun Kelase yang dibuat oleh masing-masing mahasiswa PTP menyebabkan penggunaan Kelase dapat dikontrol dengan baik oleh masing-masing pengguna, khususnya bagi mahasiswa. Menurut lqbal (2015a). Kelase merupakan jejaring sosial privat sekaligus lingkungan belajar online bagi institusi pendidikan dan organisasi. Dengan Kelase, lembaga (organisasi) akan memiliki jejaring sosial sendiri yang sifatnya terbatas hanya untuk internal anggota lembaga (organisasi) saja, hanya dapat diakses oleh guru, fasilitator, pelatih, siswa (peserta), dan orang tua (observer) yang tergabung di lembaga atau organisasi tersebut. Kelase juga bersifat fleksibel disebabkan program ini juga telah tersedia di aplikasi android, sehingga penggunaannya dapat dilakukan pada waktu dan tempat di luar jam perkuliahan formal (tatap muka)Kelase berasal dari bahasa Jawa, dengan kata dasar kelas. Kelas adalah ruangan di sekolah yang digunakan untuk kegiatan belajar mengajar, tempat guru dan siswa saling berinteraksi. Akhiran ' $e$ " di belakang kata kelas berarti 'nya' dalam bahasa Indonesia, sehingga Kelase sama artinya dengan kelasnya (Iqbal, 2015b). Kelase adalah E-learning berbasis LMS dan memiliki perangkat menarik yang dapat diakses secara mobile dan menyediakan beragam fitur menarik layaknya sosial media. Kelase diciptakan dengan konsep jejaring sosial yang memfasilitasi lingkungan belajar secara online baik untuk pendidikan formal dari tingkat SD hingga Universitas maupun pendidikan non formal seperti kursus, bimbel, home schooling dan lainnya. Kelase diharapkan dapat menjembatani hubungan antara guru, siswa, dan orang tua dalam kaitannya dengan dunia pendidikan (Iqbal, 2015C).

Mahasiswa setuju bahwa program Kelase mudah untuk dipelajari, mudah digunakan, mudah dipahami, dan mudah untuk menjadi terampil. Penilaian ini sebagai respon mahasiswa terhadap menu-menu yang disediakan oleh Kelase. Menu yang terdapat pada program Kelase menyerupai tampilan seperti media sosial dengan latar belakang yang menarik, sehingga memicu ketertarikan mahasiswa untuk menggunakan program Kelase. Selain itu, fitur-fitur yang terdapat pada Kelase juga sangat jelas sehingga memudahkan mahasiswa untuk mempelajari, menggunakan, memahami, dan terampil dalam menggunakan Kelase. Kelase dilengkapi dengan fitur Lesson Planner yang memudahkan pendidik dalam menyusun aktivitas pembelajaran, serta fitur Taxonomy Toolbox yang dapat membantu pendidik dalam menyusun tujuan pembelajaran (Iqbal, 2015d). Selain fungsi jejaring sosial, Kelase juga difokuskan untuk mendukung kegiatan pembelajaran dan pelatihan yang ada di lembaga (organisasi) dengan menyediakan fitur kelas online yang didalamnya terdapat bahan ajar, forum diskusi, penugasan, dan kuis (Iqbal, 2015a).

Penilaian mahasiswa PTP terhadap variabel ini juga ada yang bersifat raguragu, tidak setuju, bahkan sangat tidak setuju. Beberapa mahasiswa (kisaran 24-49 orang) masih memberikan penilaian ragu-ragu pada program Kelase disebabkan program "Beta Kelase" yang tersedia pada android terkadang sulit untuk dibuka. Selain itu, beberapa keluhan juga disebabkan karena iklan program Kelase lumayan banyak, sehingga mengganggu mahasiswa yang sedang login atau yang akan login 
di program tersebut, khususnya jika login melalui HP. Responden yang menyatakan tidak setuju bahkan sangat tidak setuju, sangat rendah, hanya 1-5 orang atau berkisar antara $0.53-2.62 \%$. Penilaian yang sangat rendah ini lebih disebabkan oleh alasan subjektivitas masing-masing peserta.

\section{Deskripsi Persepsi Kebermanfaatan (Perceived Usefulness)}

Variabel persepsi kebermanfaatan (perceived usefulness) terdiri dari 7 sub indikator, yaitu mempercepat pekerjaan, meningkatkan efektivitas, meningkatkan performa, meningkatkan kinerja, meningkatkan produktivitas, mempermudah pekerjaan, dan bermanfaat. Hasil penilaian responden terhadap persepsi kebermanfaatan (perceived usefulness) dapat dilihat pada Tabel 3.

Variabel persepsi kebermanfaatan (perceived usefulness) bersifat valid dan reliabel. Seluruh sub indikator yang digunakan dalam variabel menunjukkan nilai korelasi Pearson yang dihasilkan memiliki korelasi yang signifikan pada taraf 0.01. Nilai korelasi Pearson yang diperoleh pada masing-masing sub indikator berada pada kisaran 0.692-0.843. Selain itu, nilai KMO MSA dari variabel persepsi kebermanfaatan (perceived usefulness) adalah 0.871 dengan nilai factor loading masing-masing sub indikator berkisar antara 0.684-0.851. Nilai ini menunjukkan data yang diperoleh valid.

Sub indikator yang digunakan dalam pengukuran variabel persepsi kebermanfaatan (perceived usefulness) juga reliabel. Seluruh sub indikator pada variabel persepsi kebermanfaatan (perceived usefulness) menghasilkan nilai Cronbach's Alpha yang lebih besar dari 0.70 ( $>0.70$ ). Nilai Cronbach's Alpha pada variabel ini berada pada kisaran 0.850-0.874 (reliabel).

Nilai rata-rata dari masing-masing sub indikator pada variabel persepsi kebermanfaatan (perceived usefulness) berkisar antara 3.90-4.41. Nilai ini menunjukkan bahwa mahasiswa setuju dengan pernyataan pada masing-masing sub indikator. Mahasiswa PTP menilai Kelase dapat mempercepat dan mempermudah pekerjaan serta meningkatkan efektivitas, performa, kinerja, dan produktivitas. Kelase dinilai mampu meningkatkan sistem pembelajaran di PTP. Kelase merupakan salah satu sarana yang dapat digunakan tim pengajar untuk melampirkan dan menjelaskan mengenai materi-materi yang belum dikuasai dan dipahami oleh mahasiswa. Oleh karena itu, mahasiswa dapat lebih leluasa berinteraksi dan bertanya di luar jam perkuliahan mengenai hal-hal yang berkaitan dengan perkuliahan, antara lain memperoleh bahan ajar dan materi pendukung, penjelasan mengenai materi-materi kuliah yang belum dipahami langsung dari dosen yang bersangkutan, konsultasi kesesuaian referensi dengan tema tugas yang diberikan, serta tugas yang akan dikumpulkan. Seluruh proses ini menyebabkan mahasiswa lebih mudah untuk memahami materi, mengetahui apa yang akan dikerjakan, dan memiliki kepercayaan diri yang baik sehingga factor-faktor ini secara tidak langsung berpengaruh terhadap pekerjaan yang dikerjakan oleh mahasiswa serta peningkatan efektivitas, performa, kinerja, dan produktivitas.

Mahasiswa PTP, berkisar 11-48 orang (5.76-25.13\%), menilai Kelase dengan ungkapan ragu-ragu. Penilaian ini dianggap sesuatu yang wajar, karena beberapa mahasiswa masih menganggap E-learning Kelase yang diterapkan di PTP cukup berbeda dengan sistem E-learning sebelumnya atau yang telah ada. Mahasiswa 
menganggap E-learning hanya merupakan salah satu sarana dalam proses pembelajaran yang dapat digunakan sebagai proses perkuliahan secara online (tanpa tatap muka) dan sebagai jadwal pengganti jika salah satu tim dosen tidak dapat masuk mengajar dalam perkuliahan tatap muka. Khusus di Program Studi PTP, terutama mata kuliah yang digunakan sebagai sampel, metode E-learning yang diterapkan bukan dijadikan sebagai salah satu sarana untuk menggantikan jadwal mengajar dosen secara tatap muka, walaupun hal tersebut boleh, bahkan dapat dilakukan, dan tidak melanggar peraturan yang ada. Namun, proses pembelajaran Elearning yang ingin diterapkan di mata perkuliahan tersebut adalah E-learning hanya digunakan sebagai salah satu sarana untuk menjelaskan materi-materi perkuliahan di luar jam perkuliahan, sebagai wadah komunikasi antara dosen dan mahasiswa terhadap materi-materi perkuliahan yang belum dipahami oleh mahasiswa, sebagai wadah untuk memberikan bahan ajar perkuliahan ke mahasiswa, serta konsultasi mengenai tema dan referensi tugas yang akan dibuat oleh masing-masing mahasiswa.

Program E-learning Kelase yang diterapkan di Program Studi PTP dinilai sangat bermanfaat oleh mahasiswa. Hal ini ditunjukkan oleh penilaian mahasiswa PTP terhadap sub indikator bermanfaat, jumlah mahasiswa yang setuju dan sangat setuju serupa atau tidak berbeda. Jumlah mahasiswa yang setuju, yaitu 91 orang (47.64\%) dan jumlah mahasiswa yang sangat setuju, yaitu 89 orang atau $46.6 \%$. Hasil ini memperlihatkan bahwa program Kelase dapat dijadikan atau dapat direkomendasikan sebagai salah satu program E-learning yang dapat diterapkan di Prodi PTP.

\section{Deskripsi Penerimaan (Acceptance)}

Variabel penerimaan (acceptance) yang digunakan dalam penelitian ini terdiri dari 8 sub indikator, yaitu pemakaian nyata, menyenangkan, ide yang bagus, dinilai perlu, kepuasan pengguna, kontinyu, menggunakan lebih banyak, serta merekomendasikan pengguna lain. Hasil analisis validitas menunjukkan bahwa data yang digunakan bersifat valid. Seluruh sub indikator yang digunakan dalam variabel penerimaan (acceptance) menunjukkan nilai korelasi Pearson pada masing-masing sub indikator berada pada kisaran 0.673-0.775, seluruh nilai ini bernilai signifikan pada taraf 0.01. Selain itu, nilai KMO MSA dari variabel penerimaan (acceptance) adalah 0.892 dengan nilai factor loading masing-masing sub indikator berkisar antara 0.679-0.781. Hasil data KMO MSA dan nilai factor loading menunjukkan bahwa data yang diperoleh memenuhi kriteria data valid.

Hasil analisis juga menunjukkan bahwa data yang diperoleh pada variabel penerimaan (acceptance) bersifat reliabel. Nilai Cronbach's Alpha yang dihasilkan oleh seluruh sub indikator pada variabel penerimaan (acceptance) berkisar antara $0.842-0.856$. Nilai Cronbach's Alpha yang lebih besar dari $0.70(>0.70)$ menunjukkan data bersifat reliabel. Hasil analisis terhadap variabel penerimaan (acceptance) memperlihatkan mahasiswa PTP menerima dengan baik aplikasi Kelase dimanfaatkan sebagai salah satu sarana E-learning dalam proses pembelajaran di Program Studi PTP. Penilaian mahasiswa berada pada kisaran 3.88-4.26, nilai ini menunjukkan penerimaan (acceptance) mahasiswa PTP termasuk dalam kategori setuju. Mahasiswa PTP setuju bahwa Kelase dinilai perlu digunakan dan merupakan 
ide yang bagus untuk diaplikasikan dalam proses pembelajaran. Mahasiswa yang setuju bahwa Kelase dinilai perlu, yaitu 124 orang (64.92\%) dan Kelase merupakan ide yang bagus sebanyak 118 orang (61.78\%).

Mahasiswa PTP juga menyatakan bahwa Kelase adalah program yang menyenangkan dengan pemakaian nyata. Mahasiswa menganggap Kelase adalah program yang menyenangkan disebabkan karena fitur-fitur yang terdapat pada Kelase di desain seperti media sosial yang tampilannya sangat berbeda dengan aplikasi-aplikasi E-learning yang tersedia. Mahasiswa dapat berinteraksi dengan mahasiswa lain dalam kondisi yang semi formal, serupa dengan interaksi di dalam akun jejaring sosial lainnya. Selain itu, aplikasi Kelase juga telah disediakan dalam android (beta kelase), sehingga pemanfaatan Kelase bagi mahasiswa lebih mudah dan dapat digunakan setiap waktu.

Sub indikator kepuasan pengguna, kontinyu, dan menggunakan lebih banyak juga mayoritas bernilai setuju. Namun, mahasiswa yang memberi nilai ragu-ragu juga cukup tinggi, yaitu berada pada urutan kedua setelah penilaian yang termasuk dalam kategori setuju. Mahasiswa yang memberi nilai ragu-ragu berkisar antara 4553 orang atau 23.58-27.75\%. Pengguna aplikasi Kelase dengan menggunakan laptop lebih disukai dibandingkan dari penggunaan Kelase melalui HP android. Hal ini terutama disebabkan oleh banyaknya iklan-iklan yang tersedia pada saat aplikasi Kelase dibuka melalui HP android. Selain itu, jika program Kelase dibuka menggunakan HP android, beberapa HP android belum mampu untuk terkoneksi dengan baik. Program aplikasi Kelase masih cukup berat bagi HP android tertentu pada saat digunakan, sehingga terkadang menyebabkan HP lambat terkoneksi dan tiba-tiba terhenti. Hasil penilaian ini dapat menjadi acuan bagi pengembang aplikasi beta kelase pada HP android agar program aplikasi menjadi lebih baik.

Mahasiswa PTP merekomendasikan program Kelase sebagai salah satu program E-learning yang baik. Penilaian mahasiswa PTP yang setuju dan sangat setuju berada pada urutan pertama dan kedua, yaitu mahasiswa yang setuju berada pada tingkat pertama dengan persentasi 50.26\% (96 orang), dan penilaian mahasiswa yang sangat setuju agar Kelase direkomendasikan ke pengguna lain berada pada urutan kedua, yaitu $27.75 \%$ atau 53 orang. Hasil dari keseluruhan sub indikator variabel penerimaan (acceptance) memperlihatkan tingkat penerimaan mahasiswa terhadap Kelase sangat tinggi, yaitu berkisar antara 72.25-94.24\% (total persentasi mahasiswa yang memberi nilai setuju dan sangat setuju). Hasil ini menunjukkan bahwa walaupun program Kelase masih memiliki kekurangan yang perlu diperbaiki, program ini telah layak dan memenuhi standard program Elearning. Perencanaan E-learning merupakan bagian integral dari upaya perencanaan strategis institusi. Pelaksanaan mata kuliah berbasis E-learning harus memastikan lima kompetensi E-learning. Menurut Zain et al. (2015), lima kriteria tersebut adalah : (1) Intensitas pertemuan antara dosen dan mahasiswa dan antar sesama mahasiswa secara online tidak hanya untuk mendiskusikan topik pertemuan di kelas, tetapi juga sebagai ajang tukar menukar informasi layaknya layanan sosial media; (2) Diskusi online sebagai bentuk tugas mandiri dimana antar sesama mahasiswa bisa saling berkomentar sekaligus menilai; (3) Penyerahan tugas secara online yang langsung dikomentari dan dinilai dosen dimana mahasiswa bisa mengkilas balik hasil tugasnya 
sekaligus membandingkannya dengan tugas teman sejawatnya; (4) Ujian online, mahasiswa bisa langsung mengetahui, mereview, dan membandingkan hasil ujiannya dengan hasil ujian teman sejawatnya; (5) Pengelolaan nilai secara online, dosen tidak perlu repot-repot mengoreksi dan menginput nilai satu per satu, distribusi dan persentasi nilai akan tertera secara otomatis tanpa perlu ada sentuhan secara manual.

\section{Korelasi dan Linieritas Antara Variabel dengan Tingkat Penerimaan Mahasiswa PTP terhadap Kelase}

Persamaan regresi dapat terdiri dari satu peubah bebas dan satu peubah terikat atau beberapa peubah bebas dengan satu peubah terikat (Mattjik dan Sumertajaya, 2002). Analisis regresi berganda merupakan teknik analisis regresi yang dapat digunakan untuk menguji pengaruh beberapa variabel independen terhadap satu variabel dependen (Latan dan Temalagi, 2013). Dalam penelitian ini variabel independen terdiri dari persepsi kemudahan penggunaan $(\mathrm{x} 1)$ dan persepsi kebermanfaatan (x2). Variabel dependen adalah penerimaan (y).

\section{a. Pengujian Asumsi Klasik}

Pengujian asumsi klasik adalah pengujian terhadap asumsi-asumsi regresi linier yang bertujuan untuk menghindari munculnya bias dalam analisis analisis data serta untuk menghindari kesalahan spesifikasi model regresi yang digunakan. Pengujian asumsi klasik terdiri dari uji normalitas, uji multikolinearitas, uji heteroskedastisitas, dan uji autokorelasi (Latan dan Temalagi, 2013).

\section{b. Uji Normalitas}

Uji normalitas bertujuan untuk mengetahui apakah residual data dari model regresi linier memiliki distribusi normal ataukah tidak. Hasil ini menunjukkan sebaran data yang dihasilkan atau lebih dikenal dengan sebutan normal probability plot (normal P-P). Hasil yang diperlihatkan menunjukkan bahwa titik-titik plot berada dekat di sekitar garis diagonal. Hal ini dapat disimpulkan bahwa data yang dihasilkan terdistribusi normal. Uji normalitas dapat diperjelas dengan menggunakan uji statistik One-Sample Kolmogorov-Smirnov Test dan uji deskriptif. Hasil uji OneSample Kolmogorov-Smirnov Test yang dihasilkan memperlihatkan nilai asymp. Sig. (2-tailed) yang dihasilkan yaitu $0.433>0.05$. Hasil ini juga menunjukkan data yang diperoleh terdistribusi normal.

\section{c. Uji Multikolinieritas}

Uji multikolinieritas bertujuan untuk mengetahui apakah ada atau tidaknya korelasi antar variabel independen dalam model regresi. Metode yang dapat digunakan untuk menguji sifat multikolinieritas yaitu melihat nilai tolerance dan nilai VIF (Variance Inflation Factor) yang dihasilkan. Nilai tolerance untuk variabel persepsi kemudahan penggunaan dan persepsi kebermanfaatan, yaitu 0.694. Nilai keseluruhan tolerance yang dihasilkan oleh kedua variabel lebih besar dari 0.10 (> 0.10). Nilai VIF kedua variabel, baik persepsi kemudahan pengguna maupun persepsi kebermanfaatan, yaitu 1.441. Nilai VIF yang dihasilkan oleh masing-masing variabel lebih kecil dari $10(<10)$. Nilai tolerance $(>0.10)$ dan nilai VIF $(<10)$ menunjukkan data tidak memiliki masalah dengan multikolinieritas dan memenuhi persyaratan pengujian multikolonieritas. Menurut Hair et al. (2010) dalam Latan dan Temalagi 
(2013) nilai yang direkomendasikan untuk menunjukkan tidak adanya problem multikolonieritas adalah nilai tolerance harus $>0.10$ dan nilai $\mathrm{VIF}<10$.

\section{d. Uji Autokorelasi}

Uji autokorelasi bertujuan untuk mengetahui apakah ada korelasi antara kesalahan pengganggu pada data observasi satu pengamatan ke pengamatan lainnya dalam model regresi linier. Model regresi yang baik adalah yang tidak terjadi korelasi. Salah satu metode pengujian autokorelasi adalah uji statistik DurbinWatson (DW), yaitu membandingkan hasil DW statistik dengan DW tabel. Hasil yang diperoleh memperlihatkan nilai DW statistik adalah 1.903. Nilai DW tabel diperoleh dari tabel Durbin-Watson. Jumlah variabel yang digunakan ada dua $(\mathrm{k}=2)$ dengan sampel $(n=191 \approx 200)$. Nilai DW tabel pada taraf $5 \%$ yang dihasilkan dari kombinasi ini adalah lower limit (1.748) dan upper limit (1.789). Nilai DW statistik lebih besar dari nilai DW tabel $(1.903>1.789)$. Hasil ini menunjukkan bahwa tidak terdapat hubungan autokorelasi, artinya koefisien autokorelasi sama dengan nol atau tidak ada autokorelasi.

Uji autokorelasi juga dapat dilakukan menggunakan uji run test. Hasil menunjukkan nilai signifikansi yang dihasilkan pada uji run test yaitu 0.703. Nilai ini lebih besar dari 0.05 (>0.05). Nilai signifikansi yang lebih besar dari 0.05 (0.703> 0.05) menunjukkan bahwa tidak ada masalah pada autokorelasi, sehingga data disimpulkan memenuhi asumsi klasik autokorelasi.

\section{e. Uji Heteroskedastisitas}

Uji heteroskedastisitas bertujuan untuk mengetahui apakah variance dari residual data satu observasi ke observasi lainnya berbeda atau tetap. Jika varians dari residu data sama disebut homokedastisitas dan jika berbeda disebut heteroskedastisitas.

Model regresi yang diinginkan adalah homokedastisitas atau yang tidak terjadi masalah heteroskedastisitas. Salah satu uji heteroskedastisitas adalah uji scatterplot. Hasil uji scatterplot memperlihatkan titik-titik menyebar secara acak dan tidak berkumpul pada satu tempat. Namun, titik-titik plot tidak membentuk garis diagonal sempurna. Penyebaran data yang dihasilkan oleh uji scatterplot belum dapat menunjukkan data tidak bersifat heteroskedastisitas. Oleh karena itu, uji Glejser dilakukan untuk memastikan data bersifat heteroskedastisitas atau homoskedastisitas. Uji Glejser menunjukkan nilai signifikasi untuk variabel persepsi kemudahan penggunaan, yaitu 0.315, dan variabel persepsi kebermanfaatan, bernilai 0.3. Nilai signifikansi kedua variabel ini lebih besar dari 0.05 (>0.05), artinya kedua variabel ini memenuhi uji heteroskedastisitas. Oleh karena itu, kedua variabel dapat digunakan dalam model regresi linier berganda. Kedua variabel ini memenuhi uji asumsi klasik (uji normalitas, uji multikolonieritas, uji autokorelasi, dan uji heterokedastisitas).

\section{f. Pengujian Kelayakan Model}

Pengujian kelayakan model regresi linier berganda dapat dilakukan dengan melakukan beberapa pengujian. Pengujian yang dilakukan antara lain pengujian keterandalan model (uji F), pengujian koefisien regresi (uji t), dan pengujian koefisien determinasi. 


\section{g. Uji Koefisien Determinasi}

Uji koefisien determinasi menunjukkan seberapa besar kemampuan variabel independen dalam menerangkan variasi variabel dependen. Hasil uji koefisien determinasi yang dihasilkan memperlihatkan nilai adjusted $R$ square yang dihasilkan adalah 0.6 , sedangkan nilai $R$ square adalah 0.604 . Uji koefisien determinasi dapat menggunakan $R$ square atau adjusted $R$ square. Namun, penelitian ini menggunakan nilai adjusted $R$ square sebagai nilai dalam mengevaluasi model regresi. Nilai adjusted $R$ square, yaitu o.6. Nilai ini menunjukkan bahwa proporsi pengaruh variabel persepsi kemudahan penggunaan dan persepsi kebermanfaatan terhadap variabel penerimaan adalah 60\%. Artinya, variabel persepsi kemudahan penggunaan dan persepsi kebermanfaatan terhadap penerimaan $60 \%$, sedangkan sisanya $40 \%$ dipengaruhi oleh variabel lain yang tidak terdapat di dalam model regresi linier.

\section{h. Uji Keterandalan Model (Uji F)}

Uji $\mathrm{F}$ bertujuan untuk mengetahui apakah semua variabel independen yang dimasukkan dalam model regresi mempunyai pengaruh secara simultan (bersamasama) terhadap variabel dependen atau tidak. Hasil uji $F$ memperlihatkan nilai $F$ yang dihasilkan yaitu 143.251. Nilai signifikansi yaitu $0<0.05$. Hasil ini mengindikasikan bahwa semua variabel independen (variabel persepsi kemudahan penggunaan dan persepsi kebermanfaatan) secara simultan berpengaruh signifikan terhadap variabel dependen yaitu penerimaan. Hasil ini menunjukkan model regresi linier berganda yang diestimasi layak digunakan untuk menjelaskan pengaruh persepsi kemudahan penggunaan dan persepsi kebermanfaatan terhadap variabel penerimaan.

\section{i. Uji Koefisien Regresi (Uji t)}

Uji $t$ bertujuan untuk mengetahui secara individual pengaruh satu variabel independen terhadap variabel dependen. Hasil uji koefisien regresi (uji $t$ ) memperlihatkan nilai $t$ yang dihasilkan oleh variabel persepsi kemudahan penggunaan, yaitu 6.788 dengan nilai signifikansi 0. Demikian halnya, pada variabel persepsi kebermanfaatan, nilai t yang dihasilkan, yaitu 9.162 juga dengan nilai signifikansi o. Nilai signifikansi variabel persepsi kemudahan penggunaan dan persepsi kebermanfaatan lebih kecil dari 0.05 ( $0<0.05)$. Hasil ini menunjukkan bahwa secara parsial kedua variabel ini berpengaruh signifikan terhadap variabel penerimaan.

\section{j. Interpretasi Model Regresi Linier Berganda}

Interpretasi model dilakukan setelah uji asumsi klasik dan uji kelayakan model. Hal ini dilakukan agar tidak terjadi kesalahan dalam pemenuhan asumsi. Selain itu, model yang akan diestimasi juga telah diketahui kelayakannya dalam menjelaskan variabel independen yang digunakan. Persamaan model regresi linier berganda yang dihasilkan adalah :

$$
Y=4.486+0.0 .368 x 1+0.560 x 2+e
$$


Model persamaan regresi yang dihasilkan memperlihatkan variabel persepsi kemudahan penggunaan ( $\mathrm{x} 1$ ) dan persepsi kebermanfaatan (x2) bernilai positif. Persamaan regresi linier berganda yang diperoleh menjelaskan bahwa semakin baik persepsi kemudahan penggunaan yang dirasakan oleh mahasiswa di Program Studi PTP dan semakin tinggi persepsi kebermanfaatan aplikasi Kelase, maka penerimaan mahasiswa di Program Studi PTP akan semakin meningkat. Demikian pula, jika variabel persepsi kemudahan penggunaan tidak dipertahankan (menurun) dan variabel persepsi kebermanfaatan juga rendah, maka penerimaan mahasiswa di Program Studi PTP juga akan semakin rendah.

\section{KESIMPULAN}

Kesimpulan dari hasil penelitian ini adalah aplikasi Kelase merupakan salah satu program E-learning yang dapat diterima dan diterima oleh mahasiswa Program Studi Pendidikan Teknologi Pertanian (PTP) dengan tingkat penerimaan yang sangat tinggi yaitu berkisar antara 72.25-94.24\%. Tingkat penerimaan mahasiswa PTP dipengaruhi oleh variabel persepsi kemudahan penggunaan dan variabel persepsi kebermanfaatan. Variabel Technology Acceptance Model (TAM) memiliki korelasi yang signifikan. Masing-masing variabel, baik persepsi kemudahan penggunaan, persepsi kebermanfaatan, dan penerimaan saling mempengaruhi satu dengan yang lain.

Pengaruh variabel persepsi kemudahan penggunaan dan persepsi kebermanfaatan terhadap penerimaan, yaitu 60\%. Model persamaan regresi yang dihasilkan memperlihatkan variabel persepsi kemudahan penggunaan ( $x 1$ ) dan persepsi kebermanfaatan $(x 2)$ bernilai positif. Hubungan linieritas dari ketiga variabel tersebut menunjukkan bahwa semakin baik persepsi kemudahan penggunaan yang dirasakan oleh mahasiswa di Program Studi PTP dan semakin tinggi persepsi kebermanfaatan aplikasi Kelase, maka penerimaan mahasiswa di Program Studi PTP akan semakin meningkat.

\section{UCAPAN TERIMA KASIH}

Ucapan terima kasih kepada DIPA Universitas Negeri Makassar yang telah membiayai penelitian ini dengan Nomor: SP DIPA-042.01:2.400964/2018, tanggal 5 Desember 2017 Sesuai Surat Keputusan Rektor Universitas Negeri Makassar Nomor :2573/UN36/LT/2018 tanggal 03 Mei 2018

\section{DAFTAR PUSTAKA}

Djufri, M., B. Ilyas. 2007. Pengantar Metode Penelitian Sosial. Makassar : Badan Penerbit UNM.
lqbal, $\quad M$.
2015a. Pengenalan
kelase.

http://planet.kelase.net/dokumentasi/pengenalan-kelase/
Iqbal, M. 2015b. Sebenarnya Apa sih kelase.com itu. http://planet.Kelase.net/sebenarnya-apa-sih-kelase-com-itu/

Iqbal, M. 2015c. Startup Inovatif di Bidang Pendidikan Online. http://planet.kelase.net/kelase-startup-inovatif-di-bidang-pendidikan-online/ 
Iqbal, M. 2015d. Kelase.com Produk Edukasi 101 untuk Dunia Pendidikan. http://planet.kelase.net/kelase-com-produk-edukasi101-untuk-duniapendidikan/

Latan, H., S. Temalagi. 2013. Analisis Multivariate Teknik dan Aplikasi Menggunakan Program IBM SPSS 20.0. Bandung : Alfabeta.

Mattjik, A.A., I.M. Sumertajaya. 2002. Perancangan Percobaan dengan Aplikasi SAS dan Minitab, Jilid I, Edisi Kedua. Bogor : IPB Press.

Napitupulu D. 2017. Kajian Penerimaan E-Learning dengan Pendekatan Tam Study Of E-Learning Acceptance Based On Tam Approach. Prosiding Seminar Nasional Multidisiplin Ilmu Universitas Budi Luhur, 41-48.

Pasolong, H. 2013. Metode Penelitian Administrasi Publik. Bandung : Alfabeta.

Sekaran, Uma, (2000), Research Methods for Business, A Skill Bilding Approach. New York: McGraw-Hill Books Company

Setiawan W, W. Waslaluddin, M.N. Hana. 2014. Analisis Penerapan Sistem E-learning FPMIPA UPI Menggunakan Technology Acceptance Model (Tam). Jurnal Pengajaran MIPA, Vol. 19, No. 1:128-140

Sugiyono, (2009), Metode Penelitian Pendidikan, CV. Alfabeta, Bandung

Sugiyono. 2013. Metode Penelitian Administrasi Dilengkapi dengan Metode R\&D. Bandung : Alfabeta.

Sukainah A, Reski Praja P. 2017. Pengembangan Media E-learning sebagai Upaya Peningkatan Kualitas Pembelajaran pada Mata Kuliah Mikrobiologi di Program Studi Pendidikan Teknologi Pertanian Universitas Negeri Makassar. Laporan Akhir Penelitian PNBP Fakultas Teknik, Universitas Negeri Makassar

Zain R, ZA. Ahmad, N. Suyani. 2015. Implementasi, Standar Mutu, dan Penjaminan Mutu E-learning di Perguruan Tinggi. Disampaikan pada Pelatihan Penjaminan Mutu E-learning Universitas Janabadra oleh NCIE (National Consortium for Implementing E-leaning). 